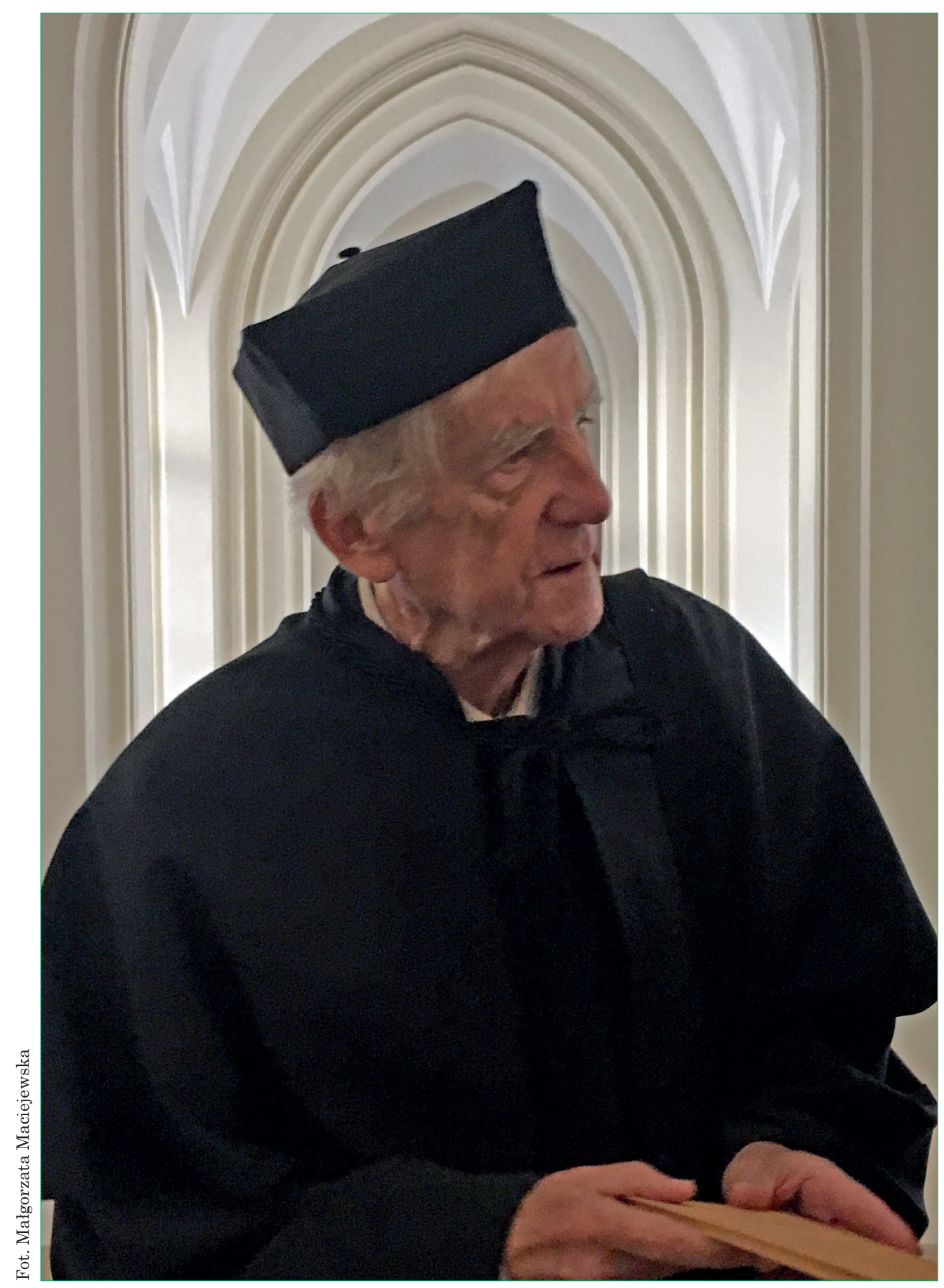

PROFESOR JACEK BALUCH

(1940-2019) 



\title{
Strukturalistyczna bohemistyka Profesora Jacka Balucha (1940-2019)
}

\begin{abstract}
Gierowski Piotr, Strukturalistyczna bohemistyka Profesora Jacka Balucha (1940-2019) [The Structural Bohemistics of Professor Jacek Baluch (1940-2019)]. „Przestrzenie Teorii” 32. Poznań 2019, Adam Mickiewicz University Press, pp. 455-467. ISSN 1644-6763. DOI 10.14746/pt.2019.32.25.

The paper describes the scientific profile of Jacek Baluch, Polish scholar and scientist in the field of Czech studies, professor of the Jagiellonian University, democratic opposition activist in the communist period in Poland, and Polish ambassador to Prague. The study emphasizes the structural aspects of Jacek Baluch's scientific work and its meaning for the development of Polish literary knowledge in the second half of the $20^{\text {th }}$ century.
\end{abstract}

KEYWORDS: Jacek Baluch, structuralism, Czech studies

3 lipca 2019 roku zmarł Profesor Jacek Baluch, jeden z najwybitniejszych polskich bohemistów drugiej połowy XX wieku, człowiek wielu talentów, badacz kultury i literatury czeskiej, tłumacz obdarzony niemałym talentem poetyckim o uchu niezwykle wyczulonym na wszelkie filologiczne subtelności, profesor Uniwersytetu Jagiellońskiego i Uniwersytetu Opolskiego, aktywny działacz opozycji demokratycznej czasów PRL internowany w okresie stanu wojennego, a w nowej rzeczywistości po roku 1989 dyplomata i ambasador RP w Czechosłowacji, a potem w Republice Czeskiej. Był on zarazem jednym z najbardziej błyskotliwych ludzi, jakich kiedykolwiek poznałem, osoba o niezwykłym uroku osobistym, niebanalnej inteligencji i dowcipie, erudytą o fantastycznej pamięci, który, jak się czasem wydawało, wiedział po prostu wszystko.

Jego dorobek naukowy jest równocześnie bardzo różnorodny, ale i wewnętrznie, zwłaszcza od strony metodologicznej, niezwykle spójny. Kariera akademicka Profesora Jacka Balucha była bowiem dobrze przemyślana pod kątem zróżnicowania podejmowanych tematów i problemów: doktorat $P o$ etyzm. Propozycja czeskiej awangardy lat dwudziestych (1969) ${ }^{1}$ poświęcony był czeskiej poezji awangardowej, rozprawa habilitacyjna Język krytyczny F.X. Śaldy $(1982)^{2}$ - problemowi krytyki literackiej, a książka profesorska Kain wedtug Hrabala $(2007)^{3}$ - jednemu z najwybitniejszych XX-wiecznych

${ }^{1}$ J. Baluch, Poetyzm. Propozycja czeskiej awangardy lat dwudziestych, Wrocław 1969.

2 J. Baluch, Język krytyczny F.X. Šaldy, Kraków 1982.

${ }^{3}$ J. Baluch, Kain wedtug Hrabala, Kraków 2007. 
czeskich prozaików Bohumilowi Hrabalowi. Zakres badań Profesora Balucha obejmował też wszystkie właściwie epoki literatury czeskiej: od epoki najstarszej, średniowiecznej (jako edytor i tłumacz wydał antologię poezji staroczeskiej Drzewo się liściem odziewa ${ }^{4}$, wspomnieć można też jego książkę poświęconą XV-wiecznej czeskiej pieśni nieprzystojnej-tzw. cantilena inhonesta-Zamazany inkaustem rękopis czyli ślasko-czeska sprośna śpiew$k a, 2013^{5}$ ), przez literaturę XIX-wieczna, po czasy współczesne. Zaznaczyć jednak wypada, że zasadniczym przedmiotem jego naukowych dociekań była przede wszystkim literatura XX-wieczna, w tym najnowsza, której był pilnym i wytrawnym obserwatorem oraz interpretatorem, nieomylnie wybierającym przy tym zjawiska najważniejsze i najciekawsze (wspominany już dorobek czeskiej awangardy, twórczość Hrabala, Milana Kundery, Václava Havla - świadectwem tych zainteresowań jest między innymi znakomity skrypt poświęcony literaturze czeskiej lat 1918-19686). Równocześnie pracy ściśle naukowej towarzyszyła w zasadzie nieustannie aktywność popularyzatorska, edytorska oraz translatorska - Jacek Baluch był między innymi autorem trzech opracowań krytycznych, które ukazały się w serii Biblioteki Narodowej: Wybór poezji Františka Halasa ${ }^{7}$, antologia Czescy symboliści, dekadenci, anarchiści przełomu XIX i XX wieku ${ }^{8}$ oraz Przygody dobrego wojaka Szwejka czasu wojny światowej Jaroslava Haška ${ }^{9}$. W jego przekładach ukazywały się dzieła wybitnych czeskich prozaików i poetów XX wieku. Wymienić tu należy zwłaszcza Społeczno-polityczna historię Partii Umiarkowanego Postęu ( $w$ Granicach Prawa) wspominanego już Haška ${ }^{10}$ (książka wielokrotnie wznawiana, doczekała się czterech wydań) czy Cierpienia księcia Sternenhocha Ladislava Klímy ${ }^{11}$, ale też i innych klasyków, takich jak: Bohumil Hrabal, Antonín Sova, Vítězslav Nezval, Fraňa Šrámek, Karel Hlaváček, Vladimír Holan czy Jiří Orten. Jego komentarze, wstępy i posłowia znajdziemy przy wydaniach utworów Karela Poláčka, Vladislava Vančury oraz Karela Čapka. Jacek Baluch tłumaczył również na język

${ }^{4}$ Drzewo się liściem odziewa. Staroczeska poezja miłosna, wybór, przekład i oprac. J. Baluch, Kraków 1981.

${ }^{5} \mathrm{~J}$. Baluch, Zamazany inkaustem rękopis czyli ślasko-czeska sprośna śpiewka, Kraków 2013.

${ }^{6}$ J. Baluch, Literatura czeska 1918-1968 r. (wykłady), Kraków 1973.

${ }^{7}$ F. Halas, Wybór poezji, oprac. J. Baluch, BN II, nr 179, Kraków 1975.

${ }^{8}$ Czescy dekadenci, symboliści $i$ anarchiści przełomu XIX $i$ XX wieku, BN II, nr 208, oprac. J. Baluch, Wrocław 1983.

${ }^{9}$ J. Hašek, Przygody dobrego wojaka Szwejka czasu wojny światowej, przeł. A. Kroh, wstęp i oprac. J. Baluch, BN II, nr 261, Wrocław 2017.

${ }^{10}$ J. Hašek, Społeczno-polityczna historia Partii Umiarkowanego Postęu (w Granicach Prawa), przeł. J. Baluch, Kraków 1987.

${ }^{11}$ L. Klíma, Cierpienia księcia Sternenhocha, przeł. J. Baluch, Kraków 1980. 
czeski - przekład Lokomotywy Juliana Tuwima na czeszczyznę uważał sam za swoje najwybitniejsze osiagnięcie translatorskie.

Zarazem jednak przy niewątpliwej różnorodności naukowych zainteresowań Profesora Balucha pewne podejmowane przez niego tematy i problemy przewijały się od samych początków jego twórczości naukowej aż po jej ostatnie lata. Wskazać tu należy przede wszystkim zainteresowanie czeska poezja, zwłaszcza w kontekście problematyki wersologicznej i przekładoznawczej (podsumowaniem tych wieloletnich badań była książka Wiersz $i$ przekład ${ }^{12}$ ). Ważnym obszarem jego naukowych dociekań była również problematyka teoretycznoliteracka, w tym zwłaszcza ta, która dotyczyła literaturoznawczego strukturalizmu - Profesor Jacek Baluch był bowiem badaczem o niezwykle wyrazistym profilu i orientacji metodologicznej. Tradycja, która go ukształtowała, był strukturalizm czeski (po części także polski). Stanowił on dla Jacka Balucha zasadniczą bazę metodologiczna, był on jego kontynuatorem, komentatorem i popularyzatorem, tłumaczył liczne prace z klasycznego dorobku Praskiej Szkoły (między innymi teksty Jana Mukařovskiego, opublikowane w znanym wyborze Wśród znaków $i$ struktur, Jiřego Levego, Květoslava Chvatíka czy Felixa Vodički, którego rozprawa Historia literatury. Jej problemy i zadania jest jednym z najczęściej przywoływanych i cytowanych naukowych przekładów Profesora Balucha - tekst ten był wydawany czterokrotnie w różnych wydawnictwach i antologiach). Jacek Baluch zwiąany był również z IBL-owskim środowiskiem polskich strukturalistów skupionych wokół Janusza Sławińskiego, uczestniczył w różnego rodzaju inicjatywach przez nich sygnowanych.

Należy tu podkreślić, że Jacek Baluch bardzo szybko przyswoił sobie strukturalistyczny metajęzyk, który w jakimś sensie stał się jego językiem naturalnym, własnym ${ }^{13}$. To znakomite opanowanie strukturalistycznego technolektu obserwować można już we wczesnych pracach i referatach Autora z połowy lat sześćdziesiątych XX wieku ${ }^{14}$. Teksty te są zaskakuja-

${ }^{12}$ J. Baluch, Wiersz i przekład, Kraków 2007.

${ }^{13} \mathrm{~W}$ analogiczny sposób opanował on zreszta język czeski - miał w zasadzie kompetencje native speakera, czego świadectwem była umiejętność wierszowania po czesku, na co wskazuje wspominany już, kongenialny przekład Lokomotywy Juliana Tuwima.

${ }^{14}$ Takich jak np.: J. Baluch, Jiři Wolker $w$ czeskiej krytyce międzywojennej, „Rocznik Komisji Historycznoliterackiej PAN”, Kraków 1964, t. 2, s. 109-138; tegoż, Program poetycki czeskiej awangardy, „Sprawozdania z posiedzeń Komisji. PAN. Oddział w Krakowie” 1964, s. 134-137; tegoż, Analiza przekładu a zagadnienie składni poetyckiej, „Sprawozdania z posiedzeń Komisji. PAN. Oddział w Krakowie” 1965, s. 152-154; tegoż, Składnia poetycka Tadeusza Różewicza w świetle przekładów na język czeski, „Slavia Occidentalis” 1965, t. 25, s. 3-13; tegoż, Problematyka badań nad czeska awangarda, „Pamiętnik Słowiański” 1966, t. XVI, s. 265-272; tegoż, Wobec czeskiej literatury wspótczesnej: Część I: Od „Května” do „Tvářy”, czyli programy literackie lat 1955-1965, „Sprawozdania z posiedzeń Komisji. PAN. Oddział 
co dojrzałe, trudno tu mówić o jakimś etapie przygotowawczym, próbnym, w którym badacz poszukuje dopiero swojego języka, podejmuje próby jego opanowania. Odbiorca zostaje skonfrontowany z twórczością naukowca bardzo młodego (Profesor Baluch rozpoczą studia uniwersyteckie w wieku lat 17, ukończył je w roku 1962, mając zaledwie 22 lata), a równocześnie w zasadzie w pełni już ukształtowanego, dojrzałego i samodzielnego, który biegle opanował swoje instrumentarium pojęciowe.

Podsumowaniem tego pierwszego okresu jego działalności naukowej była praca doktorska, która w postaci książkowej ukazała się w roku 1969 była to wspominana już monografia Poetyzm. Propozycja czeskiej awangardy lat dwudziestych. Książka ta istotna jest z kilku powodów. Ma ona niewątpliwie swoje ważne miejsce w polskiej i czeskiej bohemistyce jako oryginalne, monograficzne opracowanie ważnego (jeśli nie najważniejszego) zjawiska czeskiej awangardy literackiej okresu międzywojennego. Ale nie mniej istotny jest również sposób opracowania podejmowanej problematyki pokazanie poetyzmu jako „określonej propozycji poetyckiej [...] i estetycznej”, próba jego ujęcia „w kategorii teorii języka poetyckiego” ${ }^{15}$. Obranie takiego stanowiska metodologicznego staje się świadectwem zainteresowania Autora dochodzacym wówczas do głosu strukturalizmem i aktualnymi problemami teoretycznoliterackimi, świadectwem jego wrażliwości wobec przemian i dyskusji, które toczyły się w tym okresie w polskim literaturoznawstwie. Podkreślić tu należy aktywne uczestnictwo Profesora Balucha zarówno $\mathrm{w}$ procesie recepcji czeskiego strukturalizmu w Polsce (nie tylko poprzez wspominane przekłady, lecz także poprzez praktyczne jego wykorzystanie jako narzędzia badawczego w pracy naukowej), jak i we współtworzeniu polskiego paradygmatu strukturalistycznego, kształtowaniu języka teoretycznego, którym posługiwało się młode pokolenie polskich badaczy, takich jak Michał Głowiński, Janusz Sławiński czy Aleksandra Okopień-Sławińska. Z tym środowiskiem Profesor Jacek Baluch nawiązał bliską współpracę naukowa, stał się wręcz jego integralną częścią (uczestniczył między innymi w cyklu Ogólnopolskich Konferencji Teoretycznoliterackich Pomocniczych Pracowników Naukowych ${ }^{16}$ ), a doskonałym świadectwem owych bezpośrednich związków i inspiracji jest właśnie monografia poświęcona poetyzmo-

w Krakowie” 1966, s. 492-494; tegoż, Semantyka rymu w poetyzmie, „Sprawozdania z posiedzeń Komisji. PAN. Oddział w Krakowie” 1967, t. 11, nr 1, s. 208-211; tegoż, Przekład jako zagadnienie poetyki, „Sprawozdania z posiedzeń Komisji. PAN. Oddział w Krakowie” 1967, t. 11, nr 2, s. 710-712; tegoż, O rzemiośle poetyckim, [w:] Z polskich studiów slawistycznych. Seria 3: Prace na VI Międzynarodowy Kongres Slawistów w Pradze 1968, [Cz. 2:] Nauka o literaturze, red. Z. Libera, Warszawa 1968, s. 179-185.

${ }^{15}$ J. Baluch, Poetyzm..., s. 6, 13.

${ }^{16}$ Por. np. J. Baluch, Konferencja Teoretycznoliteracka Młodych Pracowników Polonistyki (Pcim, 2-7 lutego 1965), „Pamiętnik Literacki” 1965, R. LVI, z. 3-4, s. 605-608. 
wi, która stanowiła swego rodzaju twórczą odpowiedź i reakcję na książkę Sławińskiego Koncepcja języka poetyckiego awangardy krakowskiej z roku 1965 (czego zresztą sam Autor nie ukrywał, a wręcz podkreślał ten fakt we wstępie do swojej publikacji ${ }^{17}$ ). Związki Profesora Balucha ze środowiskiem IBL-owskim miały, co należy zaznaczyć, charakter twórczego dialogu, były obustronne, co poświadcza między innymi fakt, że termin „poetyzm” pojawił się (jako jedyne zresztą hasło bohemistyczne) w wydanym w 1976 roku Stowniku terminów literackich. Równocześnie metodologiczne zainteresowania Profesora Balucha aktualnymi trendami w polskim literaturoznawstwie pozwalały na ich stopniowe przeszczepianie na grunt polskiej slawistyki (ten aspekt również należy podkreślić, pamiętając, że polscy slawiści w procesie recepcji czeskiego strukturalizmu w Polsce mieli udział raczej niewielki, odbywała się ona przede wszystkim poprzez środowisko polonistyczne). Fakty te pozwalają zrozumieć, jak aktualną i metodologicznie trafiona publikacja była monografia poświęcona poetyzmowi (paradoksalnie jej oddźwięk i recepcja były szersze niż w przypadku pracy habilitacyjnej ${ }^{18}$ ). Zauważyć tė̇ można, że strukturalistyczne zainteresowania Jacka Balucha miały charakter trwały - był to prąd metodologiczny, któremu pozostał on wierny do końca. Oczywiście poszukiwał też inspiracji w pracach nowszych, nie tylko z klasycznego dorobku Praskiej Szkoły, sięgając po instrumentarium pojęciowe bardziej współczesnych badaczy, takich jak Tzvetan Todorov, Gerard Genette, Daniela Hodrová (czego świadectwem jest na przykład książka Kain wedtug Hrabala, o której będzie jeszcze mowa), zwykle jednak z nurtem badań strukturalnych w mniejszym czy większym stopniu związanych.

Prace i artykuły Jacka Balucha z lat siedemdziesiątych i osiemdziesiątych XX wieku wykazuja już wszystkie cechy charakterystyczne dla jego dojrzałej twórczości naukowej ${ }^{19}$. Tym, co może w nich uderzać jest wspominane już doskonałe opanowanie warsztatu badawczego, niezwykle zdyscyplinowany, rygorystyczny wręcz, tok prowadzenia wykładu naukowego oraz narracyjny dystans. W pełni ujawnia się w nich również nieprzeciętna zdolność Autora do modelowania i syntetyzowania, jego naturalna skłonność do formułowania różnego rodzaju wniosków ogólnych, do przechodzenia od

${ }^{17}$ J. Baluch, Poetyzm..., s. 13.

${ }_{18}$ Taki pogląd Profesor Baluch wyraził parokrotnie w naszych wspólnych rozmowach.

${ }^{19}$ Myślę tu zwłaszcza o takich artykułach, jak np.: J. Baluch, Przekład w kontekście metryki porównawczej, [w:] Metryka stowiańska, red. Z. Kopczyńska, L. Pszczołowska, Wrocław 1971, s. 231-243; tegoż, Mickiewicz i Stowacki w przekładach Halasa, „Slavia” 1972, R. 41, nr 3, s. 274-284; tegoż, Rym w poezji Halasa, „Pamiętnik Słowiański” 1972, t. XXII, s. 143-160; tegoż, Norma i konwencja translatorska jako kryterium oceny przektadu, ,Slavica Slovaca” (Bratysława) 1972, R. 7, nr 4, s. 353-358; tegoż, „Pierrot cyklista”-wiersz kubistyczny Nezvala, [w:] Literatury stowiańskie w okresie awangardowego przełomu, red. Z. Niedziela, Wrocław 1979, s. 143-148. 
poziomu analitycznego do poziomu twórczej syntezy i podsumowania, do werbalizowania i prezentowania teoretycznoliterackich uogólnień. Nawet w studiach i artykułach zdecydowanie analitycznych pojawiaja się zwykle interesujące uwagi o wymiarze generalizującym: można powiedzieć, że Autor nieustannie oscyluje pomiędzy poziomem analitycznym a syntetycznym, poziomem pracy nad materiałem i uwag o charakterze ogólnym, podsumowujacym. Rozprawy naukowe Jacka Balucha były w zasadzie sui generis realizacją postulatu Jana Mukařovskiego, który tak pisał o strukturalnym ujęciu relacji między badaniem materiału a teoria:

Abstrakcyjna spekulacja i konkretne opracowywanie materiału [...] są dla strukturalizmu jednym procesem: można w nim najwyżej wyróżnić dwa aspekty, z których zależnie od okoliczności jeden lub drugi uzyskuje przewagę ${ }^{20}$.

Podkreślić można w tym miejscu, że Profesor Baluch miał w swoim dorobku również prace o charakterze wybitnie teoretycznym (choć materiałem, na którym opierał swoje rozważania była zwykle literatura czeska, ewentualnie przyjmował on perspektywę komparatystyczna, polsko-czeska), takie jak na przykład Autorstwo a anonimowośćc ${ }^{21}$ czy Interpretacja przekładu ${ }^{22}$.

Dodać wreszcie należy, że trwałe zainteresowanie Jacka Balucha strukturalizmem oraz $\mathrm{w}$ zasadzie swego rodzaju naturalizacja strukturalistycznego dyskursu i strukturalistycznego instrumentarium w ramach własnej twórczości naukowej wydają się być czymś więcej aniżeli tylko wynikiem pokoleniowej mody, efektem badawczego dojrzewania i kształtowania się w takim, a nie innym literaturoznawczym paradygmacie czasowym. Pewne elementy i cechy strukturalistycznej postawy badawczej (charakterystyczne zwłaszcza dla strukturalizmu praskiego), takie jak na przykład skłonność do ujęć syntetycznych i holistycznych czy jej wyraziste językowe i językoznawcze umocowanie, znalazły - jak się wydaje - swoje doskonałe osadzenie w pewnych naturalnych i wrodzonych zdolnościach, upodobaniach i predylekcjach badacza - w jego wspominanej umiejętności syntetycznego modelowania historycznoliterackiej i kulturalnej rzeczywistości ${ }^{23}$, łatwości

${ }^{20}$ J. Mukařovský, O metodologii nauki o literaturze, przeł. J. Baluch, „Teksty” 1981, nr 1, s. 190

${ }^{21}$ J. Baluch, Autorstwo a anonimowość, [w:] Autor, podmiot literacki, bohater, red. A. Martuszewska, J. Sławiński, Wrocław 1983, s. 71-75.

${ }_{22}^{2}$ J. Baluch, Interpretacja przektadu, „Odra” 1977, nr 6, s. 29-30.

${ }^{23}$ Synteza była jednym ze słów-kluczy strukturalistycznej doktryny, tak pisał o tym problemie J. Toman: „Terminy «monografia» i «monografista» lub sformułowanie "praca na jednostkowym zjawisku [Einzelerscheinung]» są rozumiane negatywnie i prezentują moment rozejścia się z erą pozytywizmu. Nowy dyskurs, który się formował, miał stać w opozycji do starych ideałów. Wykreował on swój własny słownik, przy czym wprowadził między innymi zbiór toposów, które eksponowały odwagę do stworzenia syntezy, śmiałej wizji. Nieumiejęt- 
formułowania wniosków ogólnych, uniwersalnych, ale też w jego wyjątkowych zdolnościach językowych, w jego uwrażliwieniu na filologiczne niuanse, których był skrupulatnym i finezyjnym interpretatorem. Wydaje się, że i w taki sposób tłumaczyć można wierność Jacka Balucha wobec metody strukturalnej.

Ważne miejsce w dorobku naukowym Profesora Jacka Balucha z początku lat osiemdziesiątych XX wieku zajmowała niewątpliwie rozprawa habilitacyjna, książka Język krytyczny F.X. Šaldy ${ }^{24}$, wydana w roku 1982, choć jej ogólny zamysł powstał dużo wcześniej. Prace nad tekstem Autor prowadził niewątpliwie już od przełomu lat sześćdziesiątych i siedemdziesiątych, czego świadectwem są studia i artykuły zapowiadające przygotowywana rozprawę ${ }^{25}$. Publikacja ta wprowadza w twórczości naukowej Jacka Balucha pewne nowe kręgi tematyczne, związane z literatura czeską przełomu XIX i XX wieku (jej swego rodzaju uzupełnieniem były inne przygotowywane przekłady, antologie i skrypty ${ }^{26}$ ), a równocześnie stanowi niewątpliwą kontynuację problemów i zagadnień, którymi Autor interesował się już wcześniej. Zwrócić należy w tym wypadku uwagę przede wszystkim na konsekwentne osadzenie omawianej pracy w kontekście strukturalistycznym, i to w kil$\mathrm{ku}$ wymiarach. Z jednej strony bowiem Jacek Baluch podejmuje w swojej rozprawie zasadniczy problem związków F.X. Šaldy z tradycją strukturalistyczna (problematyce tej poświęcony jest w zasadzie cały rozdział książki pod tytułem Krytyka, metakrytyka, metodologia), z drugiej zaś odbiorcę uderza konsekwentna, strukturalna perspektywa metodologiczna, w której rozpatrywany jest omawiany problem, związana przede wszystkim z ujęciem centralnego terminu pracy - tytułowego ,języka krytycznego" - jako „systemu pojęć, norm i wartości zrealizowanych w wypowiedzi krytycznej (pojęcie stylu krytycznego oznacza w tym kontekście pewien zasób środków

ność czy niechęć napisania pracy o syntetycznym charakterze uważane były za świadectwo naukowej niemocy czy niedostatku badawczej odwagi”. J. Toman, Př́běh jednoho moderního projektu. Pražský lingvistický kroužek, 1926-1948, Praha 2011, s. 173.

${ }^{24}$ J. Baluch, Język krytyczny...

${ }^{25}$ Por. J. Baluch, „Šaldův zápisník“ (1928-1937), „Sprawozdania z Posiedzeń Komisji Naukowych. PAN. Oddział w Krakowie” 1971, t. 15, nr 2, s. 416-417; tegoż, Język krytyczny Šaldy (Tezy), [w:] Modernizm w literaturach stowiańskich (zachodnich i potudniowych). Prace krakowskiego ośrodka slawistycznego poświęcone VII Międzynarodowemu Kongresowi Slawistów w Warszawie w r. 1973, red. M. Bobrownicka, Kraków 1973, s. 39-47; tegoż, Czeska „moderna” $i$,izmy”, „Pamiętnik Słowiański” 1974, t. 24, s. 171-190.

${ }^{26}$ Por. np. przekład artykułu F.X. Šalda, Problem narodowości w sztuce, [w:] We własnych oczach. XX-wieczny esej zachodnio- i południowostowiański, wybór H. Janaszek-Ivaničkova we współpr. z E. Madanym, J. Wierzbickim i T. Dąbek-Wirgowa, Warszawa 1977, s. 27-52; skrypt Česká literatura 1892-1946. Antologie programových projevů. Pro IV ročník studentů slavistiky = dla studentów IV roku filologii słowiańskiej. Výbor, úvod, poznámky J. Baluch, J. Zarek, Katowice 1981; czy przywoływaną już antologię Czescy dekadenci... 
perswazji, podporządkowanych językowi krytycznemu)"27. Autor nie ukrywał przy tym, że zasadniczym punktem odniesienia i inspiracji były dla niego dokonania strukturalizmu polskiego, w tym zwłaszcza prace i badania Janusza Sławińskiego.

Praca poświęcona twórczości krytycznej Šaldy odznacza się także, sygnalizowanym już powyżej, typowym dla Jacka Balucha połączeniem problematyki historycznoliterackiej z zagadnieniami i problemami o charakterze teoretycznoliterackim. Świadectwem tego jest zwłaszcza ostatni rozdział książki, Język badacza wobec języka krytyki, w którym to rozdziale niewątpliwą ambicją Autora było zbudowanie uniwersalnej typologii różnorakich relacji między wypowiedziami krytycznymi, ujmowanymi jako przedmiot badawczych dociekań, a językiem metodologicznym, naukowym, w którym owe dociekania sa prowadzone. Książka ta pretendowała więc niewattpliwie do stworzenia pewnego wzorca w zakresie badań nad krytyką literacka.

Zaryzykować można wreszcie twierdzenie, że prace nad językiem krytycznym Šaldy legły także u podstaw terminologicznych i leksykograficznych zainteresowań Jacka Balucha - jak stwierdza on bowiem sam w swojej rozprawie: ,elementarny poziom rekonstrukcji języka krytycznego to zbadanie terminologii: poszczególnych terminów, ich wzajemnych powiąań wobec szerszego kontekstu pojęciowego (filozoficznego, ideologicznego itp.)" ${ }^{\prime 28}$. Zainteresowania te wraz ze wspominana już umiejętnościa syntetyzowania i modelowania literackiej i metaliterackiej rzeczywistości znalazły swój wyraz również w twórczości słownikowej Profesora Balucha, której lubił się oddawać - wymienić tu można zwłaszcza Czesko-polski słownik terminów literackich ${ }^{29}$, którego był pomysłodawcą oraz współwykonawca, popularnonaukową książkę Powiedz coś po czesku! $!^{30}$, która ma również charakter słownikowy, czy też gruntownie opracowany, lecz już niestety nieuskuteczniony, pomysł leksykonu literatury czeskiej ${ }^{31}$.

Od przełomu lat osiemdziesiątych i dziewięćdziesiątych w twórczości naukowej Jacka Balucha pojawiły się pewne nowe kręgi tematyczne związane z problemem czeskiej tożsamości narodowej ${ }^{32}$ czy aktualną sytuacją po-

27 J. Baluch, Język krytyczny..., s. 7.

28 Tamże, s. 7-8.

${ }^{29}$ J. Baluch, P. Gierowski, Czesko-polski słownik terminów literackich, Kraków 2016.

${ }^{30} \mathrm{~J}$. Baluch, Powiedz coś po czesku! Igraszki językowo-literackie, Kraków 2018.

${ }^{31}$ J. Baluch, Leksykon literatury czeskiej: projekt, „Studia Slavica” 2011, nr 15, s. 87-93.

${ }^{32}$ Por. artykuły, takie jak: J. Baluch, Idea „środka” a tożsamość czeskiej kultury, [w:] Kundera. Materiaty $z$ sympozjum zorganizowanego $w$ Katowicach $w$ dniach 25-26 kwietnia 1986, red. J. Illg, Londyn 1988, s. 11-20; tegoż, Naród czeski w ujęciu Emanuela Rádla, [w:] Język a tożsamość narodowa. Slavica, red. M. Bobrownicka, Kraków 2000, s. 53-61; przekład wraz z komentarzem słynnego eseju Jana Patočki, J. Patočka, Kim sq Czesi? przeł. J. Baluch, 
lityczną w Czechosłowacji, a później Republice Czeskiej ${ }^{33}$ (co związane było oczywiście z pełnieniem funkcji ambasadora RP w Pradze). Przeobrażeniu ulegał także styl prac naukowych Profesora Balucha: stopniowo stawał się on swobodniejszy, był niezmiennie erudycyjny, lecz bardziej anegdotyczny i gawędziarski, niekiedy wręcz emfatyczny, ujawniający wyrazistą osobowość badacza. Należy zaznaczyć, że owe ujawniające się z czasem cechy późniejszej twórczości naukowej Jacka Balucha decydowały o jej czytelniczej atrakcyjności oraz dochodzącej do głosu funkcji popularyzatorskiej (której wagę Autor niewątpliwie doceniał). Dobrym przykładem tego typu tekstu jest jego ostatnia, przywoływana już książka, publikacja w zasadzie o charakterze pogranicznym, na poły naukowa, na poły popularna: Powiedz coś po czesku!

W dorobku Profesora Balucha z tego okresu wspomnieć wypada jego książke profesorska, przywoływaną już rozprawę Kain wedtug Hrabala. Ma ona na swój sposób charakter szczególny - jest pracą zdecydowanie analityczna, koncentrująca się w zasadzie na jednym (choć dość istotnym i najprawdopodobniej najbardziej popularnym) utworze Bohumila Hrabala, noweli Pociagi pod specjalnym nadzorem. W pracy tej Autor konfrontuje Pociagi... z utworami wcześniejszymi (opowiadaniami stanowiącymi kanwę, fabularną podstawę, na której czeski prozaik oparł swoją nowelę - chodzi o utwory Kain. Opowiadanie egzystencjalne oraz Legenda o Kainie) oraz z filmową wersją tego dzieła, którą wyreżyserował Jiří Menzel. Zasadniczym celem badacza było wydobycie i pokazanie ukrytych sensów tego utworu (jego kontekstu biblijnego i egzystencjalistycznego, ujawnienie jego charakteru jako prozy inicjacyjnej), a zarazem odkrycie przed czytelnikiem istoty metody twórczej i estetyki Hrabala, opartych na palimpsestowym przepisywaniu kolejnych wersji danego dzieła (bo problem nie dotyczy jedynie Pociagów pod specjalnym nadzorem). Analiza przeprowadzana przez Jacka Balucha w ramach rozprawy ma oczywiście szersze tło, na które składa się twórczość Hrabala jako pewna historycznoliteracka całość czy problem egzystencjalizmu w literaturze czeskiej w drugiej połowie XX wieku, któremu poświęcił Autor dużą część rozdziału trzeciego książki. Ale monografia ta ma jeszcze jeden wymiar warty odnotowania - ma ona w znacznie wyższym stopniu (w stosunku do wcześniejszych książek Jacka Balucha) charakter popularnonaukowy (dominuje sygnalizowana już powyżej większa swoboda stylistyczna, ton bardziej anegdotyczny) oraz metarefleksyjny (czy też 'autotematyczny', jak określa to sam Autor,

Kraków 1997; czy tom Hrabal, Kundera, Havel... antologia czeskiego eseju, oprac. J. Baluch, Kraków 2001.

${ }^{33}$ J. Baluch, Rozpad czy podział Czechosłowacji? „Rocznik Komisji Środkowoeuropejskiej PAU” 1996, t. 4, s. 125-134. 
według którego „wykład uniwersytecki [...], także w postaci rozprawy pisanej, winien [...] nie tylko odsłaniać właściwości przedmiotu, o którym traktuje, ale także prezentować swoje własne reguły przedstawiania tego przedmiotu" ${ }^{34}$ ) - ta charakterystyczna sfera metarefleksji, która ujawniła się już wyraziście w rozprawie habilitacyjnej, tu znajduje swoje pełne rozwinięcie i realizację. Już nie jako teoretyczny dodatek do całości, lecz jako integralny i ciagle obecny element wywodu naukowego, jako nieustannie podkreślana samoświadomość badacza, jego intencjonalnie ujawniane wypowiadające ,ja”.

Zauważyć tu można pewną symptomatyczna ewolucję w pisarstwie naukowym Profesora Jacka Balucha - od tekstów niezwykle zdyscyplinowanych, poddanych rygorowi nowoczesnej nauki, w których absolutny dystans Autora zdaje się być swego rodzaju przejawem czy znakiem jego naukowej obiektywności, po teksty z wyraźnie zarysowaną osobą narratora-badacza, w których zaprasza on czytelnika do wspólnej naukowej podróży, w czasie której gwarantem jego indywidualnej badawczej rzetelności staje się ujawnienie i wyraziste zaznaczenie własnych procedur badawczych i trybu ich zastosowania. Przemianę taka potraktować można przy tym jako swego rodzaju pars pro toto, przejaw pewnej ewolucji, która zaszła w łonie samego strukturalizmu: od poziomu abstrakcyjnego i absolutnego obiektywizmu (który był jednym z zasadniczych postulatów myśli strukturalnej w początkach jej formowania się, także w kręgu Praskiego Koła Strukturalnego) do poziomu pewnej indywidualnej relacji, pewnego dążenia, w którym obiektywizm ów jest, jak pisał Edward Balcerzan, obiektywizmem „na jaki pozwalają twoje możliwości”, gwarantowanym przez prace ,, $\mathrm{W}$ miarę rzetelna ${ }^{35}$.

Opisany powyżej naukowy dorobek Profesora Jacka Balucha stanowi jedynie część jego bogatej i interesującej biografii intelektualnej, na która składała się także działalność kulturalna, polityczna i dyplomatyczna. Dla polskiej bohemistyki i slawistyki ma on niewątpliwie znaczenie doniosłe, niemało wnosi też, jak starałem się to pokazać, w rozwój polskiej nauki o literaturze w szerszym, polonistycznym kontekście - prace naukowe i translatorskie Jacka Balucha były bez wątpienia aktywnym czynnikiem, który kształtował strukturalistyczne oblicze polskiego literaturoznawstwa drugiej połowy XX wieku. Zasadniczy sens naukowej działalności tego wybitnego uczonego (która zapewne doczeka się jeszcze bardziej szczegółowego opracowania) zawiera się przede wszystkim w dążeniu, by pokazać odbiorcy czeską literaturę, sztukę i naukę jako obszar kultury innej, a jednocześnie

\footnotetext{
${ }^{34}$ J. Baluch, Kain ..., s. 13.

${ }^{35}$ E. Balcerzan, „I ty zostaniesz strukturalista”, ,Teksty” 1973, nr 6, s. 4.
} 
w pełni dojrzałej i autonomicznej, obszar, z którego czerpać możemy inspirację, z którym prowadzić możemy twórczy dialog i którego poznanie pozwala nam również na nieco inne spojrzenie na nasz własny kontekst i dorobek kulturalny.

Znajomość i przyjaźń z Jackiem Baluchem (bo tak mogę chyba określić naszą relację w ostatnich latach) była dla mnie niewątpliwie niezwykła przygodą intelektualna, pustka po Jego śmierci utwierdza mnie natomiast w przekonaniu, że, wbrew powszechnemu mniemaniu, istnieja jedynie ludzie niezastapieni - a w każdym razie taką osobą był Profesor.

\section{BIBLIOGRAFIA}

Balcerzan E., „I ty zostaniesz strukturalista”, „Teksty” 1973, nr 6.

Baluch J., Analiza przektadu a zagadnienie sktadni poetyckiej, „Sprawozdania z posiedzeń Komisji. PAN. Oddział w Krakowie" 1965.

Baluch J., Autorstwo a anonimowość, [w:] Autor, podmiot literacki, bohater, red. A. Martuszewska, J. Sławiński, Wrocław 1983.

Baluch J., Czeska „moderna” i ,izmy”, „Pamiętnik Słowiański” 1974, t. 24.

Baluch J., Idea „środka” a tożsamość czeskiej kultury, [w:] Kundera. Materiały z sympozjum zorganizowanego $w$ Katowicach $w$ dniach 25-26 kwietnia 1986, red. J. Illg, Londyn 1988.

Baluch J., Interpretacja przektadu, „Odra” 1977, nr 6.

Baluch J., Język krytyczny F.X. Šaldy, Kraków 1982.

Baluch J., Język krytyczny Šaldy (Tezy), [w:] Modernizm w literaturach stowiańskich (zachodnich i potudniowych). Prace krakowskiego ośrodka slawistycznego poświęcone VII Międzynarodowemu Kongresowi Slawistów w Warszawie w r. 1973, red. M. Bobrownicka, Kraków 1973.

Baluch J., Jiří Wolker w czeskiej krytyce międzywojennej, „Rocznik Komisji Historycznoliterackiej PAN", Kraków 1964, t. 2.

Baluch J., Kain wedtug Hrabala, Kraków 2007.

Baluch J., Konferencja Teoretycznoliteracka Młodych Pracowników Polonistyki (Pcim, 2-7 lutego 1965), „Pamiętnik Literacki” 1965, R. LVI, z. 3-4.

Baluch J., Leksykon literatury czeskiej: projekt, „Studia Slavica” 2011, nr 15.

Baluch J., Literatura czeska 1918-1968 r. (wyktady), Kraków 1973.

Baluch J., Mickiewicz i Stowacki w przektadach Halasa, „Slavia” 1972, R. 41, nr 3.

Baluch J., Naród czeski w ujęciu Emanuela Rádla, [w:] Język a tożsamość narodowa. Slavica, red. M. Bobrownicka, Kraków 2000.

Baluch J., Norma i konwencja translatorska jako kryterium oceny przekładu, „Slavica Slovaca" (Bratysława) 1972, R. 7, nr 4.

Baluch J., O rzemiośle poetyckim, [w:] Z polskich studiów slawistycznych. Seria 3: Prace na VI Międzynarodowy Kongres Slawistów w Pradze 1968, [Cz. 2:] Nauka o literaturze, red. Z. Libera, Warszawa 1968. 
Baluch J., „Pierrot cyklista”- wiersz kubistyczny Nezvala, [w:] Literatury słowiańskie $w$ okresie awangardowego przełomu, red. Z. Niedziela, Wrocław 1979.

Baluch J., Poetyzm. Propozycja czeskiej awangardy lat dwudziestych, Wrocław 1969.

Baluch J., Powiedz coś po czesku! Igraszki językowo-literackie, Kraków 2018.

Baluch J., Problematyka badań nad czeskq awangarda, „Pamiętnik Słowiański” 1966, t. XVI.

Baluch J., Program poetycki czeskiej awangardy, „Sprawozdania z posiedzeń Komisji. PAN. Oddział w Krakowie" 1964.

Baluch J., Przektad jako zagadnienie poetyki, „Sprawozdania z posiedzeń Komisji. PAN. Oddział w Krakowie” 1967, t. 11, nr 2.

Baluch J., Przekład w kontekście metryki porównawczej, [w:] Metryka słowiańska, red. Z. Kopczyńska, L. Pszczołowska, Wrocław 1971.

Baluch J., Rozpad czy podziat Czechosłowacji? „Rocznik Komisji Środkowoeuropejskiej PAU” 1996, t. 4.

Baluch J., Rym w poezji Halasa, „Pamiętnik Słowiański” 1972, t. XXII.

Baluch J., „Šaldův zápisník“(1928-1937), „Sprawozdania z Posiedzeń Komisji Naukowych. PAN. Oddział w Krakowie” 1971, t. 15, nr 2.

Baluch J., Semantyka rymu w poetyzmie, „Sprawozdania z posiedzeń Komisji. PAN. Oddział w Krakowie" 1967, t. 11, nr 1.

Baluch J., Składnia poetycka Tadeusza Różewicza w świetle przekładów na język czeski, „Slavia Occidentalis” 1965, t. 25.

Baluch J., Wiersz i przektad, Kraków 2007.

Baluch J., Wobec czeskiej literatury wspótczesnej: Czesść I: Od „Května” do „Tvářy”, czyli programy literackie lat 1955-1965, „Sprawozdania z posiedzeń Komisji. PAN. Oddział w Krakowie" 1966.

Baluch J., Zamazany inkaustem rękopis czyli ślasko-czeska sprośna śpiewka, Kraków 2013.

Baluch J., Gierowski P., Czesko-polski słownik terminów literackich, Kraków 2016.

Česká literatura 1892-1946. Antologie programových projevů. Pro IV ročník studentů slavistiky = dla studentów IV roku filologii słowiańskiej. Výbor, úvod, poznámky J. Baluch, J. Zarek, Katowice 1981.

Czescy dekadenci, symboliści i anarchiści przełomu XIX $i$ XX wieku, BN II, nr 208, oprac. J. Baluch, Wrocław 1983.

Drzewo się liściem odziewa. Staroczeska poezja miłosna, wybór, przekład i oprac. J. Baluch, Kraków 1981.

Halas F., Wybór poezji, oprac. J. Baluch, BN II, nr 179, Kraków 1975.

Hašek J., Przygody dobrego wojaka Szwejka czasu wojny światowej, przeł. A. Kroh, wstęp i oprac. J. Baluch, BN II, nr 261, Wrocław 2017.

Hašek J., Społeczno-polityczna historia Partii Umiarkowanego Postępu (w Granicach Prawa), przeł. J. Baluch, Kraków 1987.

Hrabal, Kundera, Havel... antologia czeskiego eseju, oprac. J. Baluch, Kraków 2001.

Klíma L., Cierpienia księcia Sternenhocha, przeł. J. Baluch, Kraków 1980.

Mukařovský J., O metodologii nauki o literaturze, przeł. J. Baluch, „Teksty” 1981, nr 1.

Mukařovský J., Wśród znaków i struktur, wybór, redakcja i słowo wstępne J. Sławiński, Warszawa 1970. 
Patočka J., Kim sq Czesi? przeł. J. Baluch, Kraków 1997.

Toman J., Příběh jednoho moderního projektu. Pražský lingvistický kroužek, 1926-1948, Praha 2011.

We własnych oczach. XX-wieczny esej zachodnio- i południowostowiański, wybór H. Janaszek-Ivaničkova we współpr. z E. Madanym, J. Wierzbickim i T. Dąbek-Wirgowa, Warszawa 1977. 
